\title{
BIOPHYSICAL PARAMETERS TO THE SURFACE BY ORBITAL REMOTE SENSING IN HYDROGRAPHIC BASIN OF THE BRAZILIAN SEMIARID
}

\author{
PARÂMETROS BIOFÍSICOS À SUPERFÍCIE POR SENSORIAMENTO REMOTO ORBITAL EM BACIA HIDROGRÁFICA DO \\ SEMIÁRIDO BRASILEIRO
}

PARÁMETROS BIOFÍSICOS DE LA SUPERFICIE POR DETECCIÓN REMOTA ORBITAL EN UNA CUENCA HIDROGRÁFICA EN LA SEMIÁRIDA BRASILEÑA

\begin{abstract}
Introduction: The Brazilian semiarid region is characterized in many places by its negative water balance, irregular rainfall and the predominance of the Caatinga biome. Anthropic actions have impacted on changes in land use and threatened the Caatinga. In this way, remote sensing is a key tool for investigating environmental impacts, planning and making decisions about water and natural resources. Objective: The objective of this work was to monitor and evaluate biophysical parameters of the terrestrial surface in the dry period in the Brazilian semiarid hydrographic basin by remote sensing techniques. Methods: The study area selected was the hydrographic basin of the Exu stream, which is located in the semiarid Pernambuco. The development of the study took place through three orbital images provided by NASA/USGS, in which the Surface Energy Balance Algorithm for Land (SEBAL) was implemented. Results: Vegetation dynamics did not differ significantly between the images, independent if the year was dry, normal, or rainfall, because the response of vegetation growth occurs on a daily scale, depending on precipitation. In general, it was observed that the increase of the vegetation indices reflected in lower values for albedo and surface temperature. Conclusions: Remote sensing allowed the environmental monitoring of the hydrographic basin in the semiarid region, effectively assessing the environmental changes of the region, both in the face of local climate variations, and also through anthropic actions on land use and occupation.
\end{abstract}

Keywords: Caatinga; Albedo; Vegetation dynamics; Energy balance; Agrometeorology.

\section{RESUMO}

Introdução: O Semiárido brasileiro é caracterizado em muitos locais por seu balanço hídrico negativo, precipitação irregular e predominância do bioma Caatinga. As ações antrópicas têm impactado em alterações no uso do solo e ameaçado a Caatinga. Desta forma, o sensoriamento remoto é uma ferramenta chave para investigação dos impactos ambientais, planejamento e tomada de decisões sobre os recursos hídricos e naturais. Objetivo: O objetivo deste trabalho foi monitorar e avaliar parâmetros biofísicos da superfície terrestre no período seco em bacia hidrográfica do semiárido brasileiro por meio de técnicas de sensoriamento remoto. Métodos: A área de estudo selecionada foi a bacia hidrográfica do riacho Exu, localizada no semiárido Pernambucano. 0 estudo foi desenvolvido através do processamento digital de três imagens orbitais fornecidas pela NASA/USGS, nas quais foram implementadas o Surface Energy Balance Algorithm for Land (SEBAL). Resultados: A dinâmica da vegetação não diferiu significativamente entre as imagens, independente se o ano foi seco, normal ou chuvoso, porque a resposta do crescimento da vegetação ocorre em uma escala diária, dependendo da precipitação. De maneira geral, observou-se que o aumento dos índices de vegetação refletiu em menores valores para albedo e temperatura de superfície. Conlusões: $O$ sensoriamento remoto permitiu o monitoramento ambiental da bacia hidrográfica na região semiárida, avaliando efetivamente as
Drederico Abraão Costa Lins ${ }^{a}$ De Geber Barbosa de Albuquerque Moura ${ }^{\text {b }}$

(D) Pabrício Marcos Oliveira Lopes ${ }^{b}$ (D) Jhon Lennon Bezerra da Silva ${ }^{a}$ (D) Cristina Rodrigues Nascimento ${ }^{b}$ D Ênio Farias de França e Silva ${ }^{a}$

${ }^{a}$ Rural Federal University of Pernambuco (UFPE), Recife, PE, Brazil.

DOI: $10.12957 /$ geouerj.2021.39650

Correspondence:

frederico_acl@hotmail.com

Received in: 24 jan. 2019

Accepted in: 30 mar. 2021 
mudanças ambientais da bacia, tanto em face das variações climáticas locais, quanto através de ações antrópicas de uso e ocupação do solo.

Palavras-chave: Caatinga; Albedo; Dinâmica da vegetação; Balanço de energia; Agrometeorologia.

\section{RESUMEN}

Introducción: La región semiárida brasileña se caracteriza en muchos lugares por su balance hídrico negativo, lluvias irregulares y el predominio del bioma Caatinga. Las acciones antrópicas han impactado en los cambios en el uso de la tierra y han amenazado a la Caatinga. De esta forma, la teledetección es una herramienta clave para investigar los impactos ambientales, planificar y tomar decisiones sobre el agua y los recursos naturales. Objetivo: El objetivo de este trabajo fue monitorear y evaluar parámetros biofísicos de la superficie terrestre en el período seco en la cuenca hidrográfica semiárida brasileña mediante técnicas de teledetección. Métodos: El área de estudio seleccionada fue la cuenca hidrográfica del arroyo Exu, que se ubica en el semiárido Pernambuco. El desarrollo del estudio se llevó a cabo a través de tres imágenes orbitales proporcionadas por NASA / USGS, en las que se implementó el Algoritmo de Balance de Energía de Superficie para Tierra (SEBAL). Resultados: La dinámica de la vegetación no difirió significativamente entre las imágenes, independientemente de si el año fue seco, normal o lluvioso, debido a que la respuesta del crecimiento de la vegetación ocurre a escala diaria, dependiendo de la precipitación. En general, se observó que el aumento de los índices de vegetación se reflejó en valores más bajos de albedo y temperatura superficial. Conclusiones: La teledetección permitió el monitoreo ambiental de la cuenca hidrográfica de la región semiárida, evaluando eficazmente los cambios ambientales de la región, tanto ante las variaciones climáticas locales, como también a través de acciones antrópicas de uso y ocupación del suelo.

Palabras clave: Región Metropolitana, Estatuto de Metrópolis, RMBH, RMVA, Montes Claros. 
INTRODUCTION

In several localities of the world, the semiarid climate it's present and is generally characterized by irregular rains and/or absence, low humidity, and high temperatures, as highlighted in several studies (ENGLE, 2012; BRANDT et al., 2014; MARIANO et al., 2018). The Brazilian semiarid, for example, formed by a set of spaces that characterized by negative water balance, resulting from average annual rainfall less than $800 \mathrm{~mm}$, average heatstroke of $2800 \mathrm{~h}_{\text {year }}{ }^{-1}$, average annual temperatures of 23 to $27 \stackrel{\circ}{ } \mathrm{C}$, evaporation of $2000 \mathrm{~mm}$ year $^{-1}$ and relative humidity of around 50\% (MOURA et al., 2007). These regions main Caatinga biome, which is one of the most threatened biomes in Brazil, with much of its area is greatly modified by the anthropic actions and extreme natural conditions of the region, mainly because of the strong cycles of droughts and irregularity of the rains, causing low rainfall (HASTENRATH, 2012; PALÁCIO et al., 2013; GUTIÉRREZ et al., 2014; RODRIGUEZ et al., 2015; MARIANO et al., 2018).

With the advancement of science, it is increasingly sought to investigate anthropic actions and their relationship with land use and occupation, especially in semiarid regions inserted in the Brazilian Northeast. It becomes essential to know the physical processes that involve the energy and mass changes between the surface and the atmosphere depends on the use and coverage of the soil, mainly in the hydrographic basin. The remote sensing techniques allow the environmental monitoring and evaluation of biophysics parameters through algorithms, in particular, the Surface Energy Balance Algorithm for Land (SEBAL), which show quite accurate estimates such as albedo and surface temperature and on the vegetation condition through vegetation indexes such as NDVI (Normalized Difference Vegetation Index), SAVI (Soil Adjusted Vegetation Index) and LAI (Leaf Area Index) (BASTIAANSSEN et al., 1998a; BASTIAANSSEN, 2000; ALLEN et al, 2002; BEZERRA et al., 2014; ZHANG et al., 2016; LINS et al., 2017).

Due to the lack of data and studies in the semiarid region, remote orbital sensing has a high advantage in cost/benefit relation, associating meteorological and morphological information of the study area to get biophysical data, contributing to the quantitative and cartographic physical understanding through images orbitals of satellites, which may aid in the management and conservation of the environment, minimizing the negative impacts resulting from the inadequate use of water and natural resources (BASTIAANSSEN et al., 2010; OLIVEIRA et al., 2014; PACHECO et al., 2014). The hydrographic basin of the Exu stream, in the semiarid of Pernambuco, is a fundamental unit to support planning and decision-making concerning water and natural resources, the use of estimates of biophysical parameters by remote sensing techniques, as an important tool in detecting possible environmental changes. This study aimed to check and evaluate biophysical parameters of the terrestrial surface in the dry period in the basin of the Brazilian semiarid region using remote sensing techniques using orbital satellite images. 


\section{MATERIAL AND METHODS}

\section{LOCATION OF THE STUDY AREA}

The study area is the hydrographic basin of the Exu stream located in the following geographical coordinates: $8^{\circ} 00^{\prime} 06^{\prime \prime}$ S and $38^{\circ} 25^{\prime} 43^{\prime \prime}$ W) located in the Sertão do Pajeú in the municipality of Serra Talhada, Pernambuco, Brazil.

Figure 1 presents the study area from a Landsat-8 satellite orbital image of the sensor OLI on September 20,2016 , which also highlights the meteorological station and the place of the city near the region.

Figure 1. Spatial map of the hydrographic basin of the Exu stream, Serra Talhada-PE
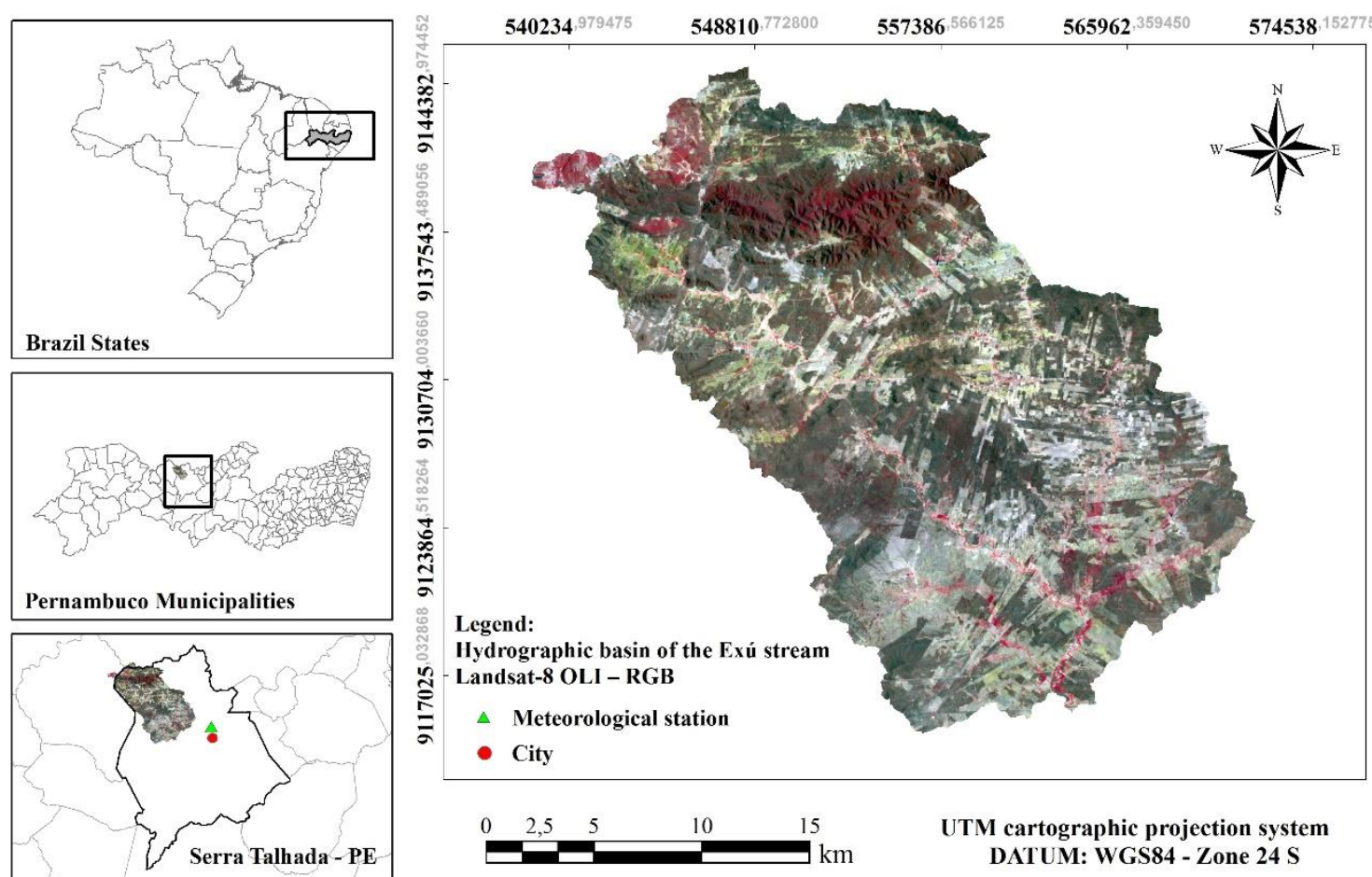

\section{CLIMATIC CHARACTERIZATION OF THE STUDY AREA}

The region is characterized by a semiarid climate, hot and dry, with an average annual temperature above $30 \stackrel{\circ}{ } \cong$ and rainfall in the range of $400-800 \mathrm{~mm}$ per year, with summer rains that fall in autumn. According to Köppen (1936), the climatic classification of the region is BSh (ALVARES et al., 2013). The rainfall season begins in November and extends through April (CPRM, 2005). The hydrographic basin of the Exu stream has from young soils like Neosols, to more evolved soils like Argisols also occurring Plansols and Cambisols (SANTOS \& GALVÍNCIO, 2013). 


\section{METEOROLOGICAL DATA}

Average temperature data was acquired from instant air $\left(\mathrm{T}_{\text {air, }}{ }^{\circ} \mathrm{C}\right)$, relative humidity $(\mathrm{RH}, \%)$ atmospheric pressure of the instantaneous air, $\left(\mathrm{P}_{\mathrm{o}}, \mathrm{kPa}\right)$ obtained from the National Institute of Meteorology (INMET) these recorded automatically in the Data collection platform, code: 32285 - Station: Serra Talhada-PE, located the following coordinates, Latitude $7^{\circ} 55^{\prime} 30^{\prime \prime} \mathrm{S}$ and Longitude $38^{\circ} 17^{\prime} 13^{\prime \prime} \mathrm{W}$, Altitude of $430 \mathrm{~m}$. Surface meteorological data required to do corrections and calibration of the images obtained according to Table 1.

Table 1. Surface meteorological data recorded by the automatic station at the moments of the satellite imagery.

\begin{tabular}{ccccc}
\hline Date & Schedule & $\mathbf{T}_{\text {air }}$ (ㅇ) & RH (\%) & Po $_{\text {(kPa) }}$ \\
\hline 09/26/1989 & 09h07min & 26 & 60 & 96.4 \\
09/01/2009 & 09h31min & 25 & 52 & 96.4 \\
09/20/2016 & 09h01min & 27.3 & 41 & 95.9 \\
\hline
\end{tabular}

\section{ORBITAL DATA}

The present research conducted from three orbital images, two of the Landsat-5 TM (Thematic Mapper) satellites and one from Landsat-8 OLI/TIRS (Operational Land Imager/Thermal Infrared Sensor), which acquired from the USGS/NASA US website (United States Geological Survey/National Aeronautics and Space Administration). The following criteria adopted for choosing the images: clear sky condition or less than 10\% of clouds, the presence of clouds may underestimate or overestimate the values of the images. Another criterion was that the images inserted in the dry period of years classified as dry (09/20/2016), normal (09/01/2009), and rainfall (09/26/1989) using the quantiles technique (XAVIER et al., 2002) according to the precipitation the historical series of the period from 1986 to 2016.

The rains preceding the satellite passes were taken into consideration in the discussions. In 30 days before the passages of the satellites observed rainfall smaller than $10 \mathrm{~mm}$ for an image of the year 2016, up to $30 \mathrm{~mm}$ for the 2009 image, and $11 \mathrm{~mm}$ for the year 1989, at the previous 15 days, $0 \mathrm{~mm}$ of rainfall observed in the year 2016, $27 \mathrm{~mm}$ for the year 2009 and $4.4 \mathrm{~mm}$ for the year 1989.

The acquired images are orthorectified and georeferenced. They have orbit: 216 and point: 65 , covering the study area. The UTM (Universal Transverse Mercator) geographical projection system, DATUM: WGS 1984 on 24 South zone. Sequential day Data of the Year - SDY, solar elevation (E), solar zenith angle $(\theta)$, average distance Earth-Sun for the day images $\left(d_{r}\right)$, and instantaneous atmospheric transmissivity in the field of solar radiation for days of clear sky $\left(\tau_{s w}\right)$. Table 2 highlights the main orbital information of satellite images. 
Table 2. Input variables for the processing of orbital images at the moments of the satellite passages in the study area

\begin{tabular}{lllllll}
\hline $\begin{array}{l}\text { Satellite } \\
\text { Landsat }\end{array}$ & Date of image & SDY & E (degrees) & $\boldsymbol{0}$ & $\mathbf{d}_{\mathbf{r}}$ & $\boldsymbol{\tau}_{\mathbf{s w}}$ \\
\hline 5-TM & $09 / 26 / 1989$ & 269 & 55.220 & 0.821 & 0.997 & 0.737 \\
5-TM & $09 / 01 / 2009$ & 244 & 55.873 & 0.827 & 0.983 & 0.745 \\
8-OLI/TIRS & $09 / 20 / 2016$ & 264 & 62.665 & 0.888 & 0.994 & 0.758 \\
\hline
\end{tabular}

\section{PROCESSING STEPS IN THE SEBAL ALGORITHM}

Atmospheric correction was carried out using the orbital images in each multispectral band. The atmospheric correction method used was by dark pixel subtraction (DOS), which aims to estimate and remove the atmospheric scattering of the multispectral bands. Therefore, in any spectral bands, there are dark pixels in the image, such as they should assume the value " 0 ", which in general can be cloud shadows and/or caused by the topography, which should have a very low digital number in the image, equivalent to about $1 \%$ reflectance (CHAVEZ, 1988; CHAVEZ, 1989).

In digital processing, the Semi-automatic classification plugin of the QGIS software (version 2.18) was used to perform the atmospheric correction, and also performed the radiometric calibration for each band in an automated way through the metadata of the images, obtaining the monochromatic reflectance, which is essential to estimate the parameters. biophysical.

Next steps: stacking bands 1 to 7 of Landsat-5 TM and 2 to 7 and band 10 for Landsat-8 OLI/TIRS, trim of the study area. The SEBAL algorithm was implemented to process the biophysical parameters of albedo and surface temperature and vegetation indices (NDVI, SAVI, and LAI) (BASTIAANSSEN et al., 1998ab; BASTIAANSSEN, 2000; ALLEN et al., 2002). Figure 2 shows the flowchart with the processing steps from the atmospheric correction to the biophysical parameters using SEBAL to the surface temperature.

Figure 2. Flowchart of the processing steps of the biophysical parameters by the SEBAL algorithm.

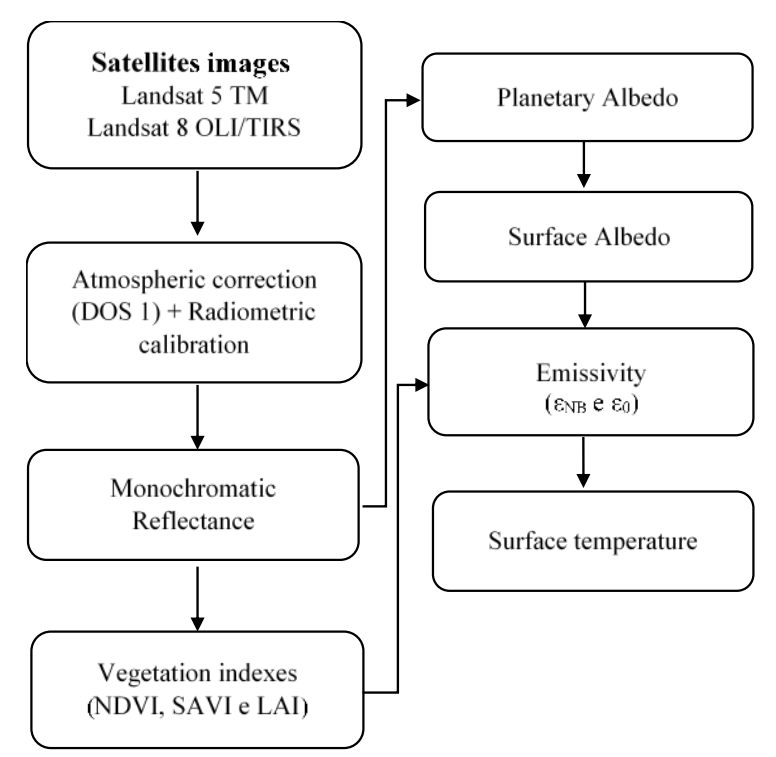


For calculation of the spectral radiance in each band of Landsat-5 have used Equation 1 as Chander et al. (2009).

$$
L_{b}=L_{\min b}+\left(\frac{L_{\max b}-L_{\min b}}{255}\right)\left(N D_{b}-1\right)
$$

Where $L_{b}\left(W m^{-2} \mathrm{sr}^{-1} \mu \mathrm{m}^{-1}\right)$ is the radiance of each pixel in each band; $b$ (subscript) represents the Landsat-5 TM bands; $L_{\max } \mathrm{b}$ and $L_{\min }$ b are the minimum and maximum spectral radiance $\left(\mathrm{W} \mathrm{m}^{-2} \mathrm{sr}^{-1} \mu \mathrm{m}^{-1}\right)$, respectively, according to Table 3; ND is the pixel intensity (digital number - integer 0 to 255).

Table 3. Description of Landsat-5 Thematic Mapper (TM) bands with calibration coefficients (minimum radiance - $L_{\text {min }}$ and maximum $L_{\max }$ for the period: before May/2003 ( $\left.L_{\max 1}\right)$, May/2003 to April/2007 $\left(L_{\max 2}\right)$ after April/2007 $\left.\left(L_{\max 3}\right)\right)$ and spectral irradiance in the atmosphere buffer (TOA).

\begin{tabular}{|c|c|c|c|c|c|c|}
\hline \multirow[t]{2}{*}{ Band } & \multirow{2}{*}{$\begin{array}{l}\text { Wavelength } \\
\qquad(\mu \mathrm{m})\end{array}$} & \multicolumn{4}{|c|}{$\begin{array}{c}\text { Calibration coefficient of Landsat-5 } \\
\text { TM }\left(\mathbf{W ~ m}^{-2} \mathbf{s r}^{-1} \mu \mathbf{m}^{-1}\right)\end{array}$} & \multirow{2}{*}{ 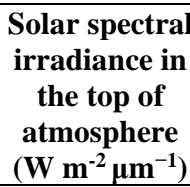 } \\
\hline & & Lmín & $L_{\max 1}$ & $\mathbf{L}_{\max 2}$ & $\mathbf{L}_{\max 3}$ & \\
\hline 1 (Blue) & $0.45-0.52$ & -1.52 & 152.10 & 193 & 169 & 1957 \\
\hline 2 (Green) & $0.52-0.60$ & -2.84 & 296.81 & 365 & 333 & 1796 \\
\hline 3 (Red) & $0.63-0.69$ & -1.17 & 204.30 & 264 & 264 & 1536 \\
\hline 4 (IR-Near) & $0.76-0.90$ & -1.51 & 206.20 & 221 & 221 & 1031 \\
\hline 5 (IV-Medium) & $1.55-1.75$ & -0.37 & 27.19 & 30.2 & 30.2 & 220 \\
\hline 6 (IV-Thermal) & $10.4-12.5$ & 1.2378 & 15.303 & 15.303 & 15.303 & - \\
\hline 7 (IV-Medium) & $2.08-2.35$ & -0.15 & 14.38 & 16.5 & 16.0 & 83.44 \\
\hline
\end{tabular}

The calibration coefficients determined of the additive and multiplicative terms, made available in the image metadata by NASA. To convert the ash-level values of each satellite band into spectral radiance and monochromatic reflectance followed the NASA criteria used in studies by Chander et al. (2009) and Silva et al. (2016). To find the radiance, we used Equation 2.

$$
\mathrm{L}_{\mathrm{b}}=\mathrm{Add}_{\mathrm{rad} \mathrm{b}}+\text { Mult }_{\mathrm{rad} b} \cdot \mathrm{ND}_{\mathrm{b}}
$$

Where Add $_{\text {rad } b}$ is the additive term and Mult ${ }_{r a d}$ is the multiplicative term, all referring to radiance and $N D_{b}$ is the size of each pixel for the "b" band in question.

The determined reflectance was necessary to calculate the relative distance between the Earth-Sun ( $\left.d_{r}\right)$, according to Equation 3 (IQBAL, 1983).

$$
d_{r}=1+0.033 \cdot \cos \left(\frac{S D Y .2 \cdot \pi}{365.25}\right)
$$


Where SDY is the sequential day of the year and the argument of the cos (cosine) function is in radians.

The monochrome reflectance is measured as a function of the solar zenith angle and distance on EarthSun for each band of Landsat-5 TM satellite as Equation 4.

$$
r_{b}=\frac{\pi \cdot L_{b}}{k_{b} \cdot \cos \theta \cdot d_{r}}
$$

Where $r_{b}\left(W^{-2} s^{-1} \mu m^{-1}\right)$ monochromatic reflectance of each pixel in each band $(b) ; k_{b}\left(W^{-2} \mu m^{-1}\right)$ solar constant associated with the reflective bands of Landsat-5 TM, as employed and proposed by Chander et al. (2009).

The monochromatic reflectance $\left(r_{b}\right)$ for the Landsat-8 OLI image is given by Equation 5 , where it was necessary to transform the quantized and calibrated values of the gray level of each reflective band "b" (two to seven) of the OLI to reflectance.

$$
r_{b}=\frac{\left(\text { Add }_{r e f b}+\text { Mult }_{r e f b} \cdot N D_{b}\right)}{\cos \theta \cdot d_{r}}
$$

Where $\operatorname{Add}_{\mathrm{ref} b}$ is the additive term and the Multref $\mathrm{b}$ is the multiplicative relative on the reflectance and $N D_{b}$ is the intensity of each pixel in each band.

The planetary albedo ( $\alpha_{\text {toa }}$ ) for Landsat-5 satellite images estimated according to Silva et al. (2005a) and Bezerra et al. (2014), according to Equation 6.

$$
\alpha_{\text {toa }}=0.293 \cdot r_{1}+0.274 \cdot r_{2}+0.233 \cdot r_{3}+0.157 \cdot r_{4}+0.033 \cdot r_{5}+0.011 \cdot r_{7}
$$

The weights of the above equation correspond to the value of the monochromatic solar irradiance $\left(\mathrm{k}_{\mathrm{b}}\right)$ of each band (Table 3 ) by the sum of the irradiance bands $\left(\Sigma k_{b}\right)$, that is: band weight $b=k_{b} / \Sigma k_{b}$ (SILVA et al., 2005a; BEZERRA et al., 2014).

We calculated the weight coefficients ( $\left.p_{b}\right)$ for each band "b" (Silva et al., 2016).

$$
k_{b}=\frac{\pi \cdot L_{b}}{r_{b} \cdot \cos \theta \cdot d_{r}}
$$


Where, $\mathrm{k}_{\mathrm{b}}\left(\mathrm{W} \mathrm{m}^{-2} \mu \mathrm{m}^{-1}\right)$ solar constant associated with each reflective band $\mathrm{r}_{\mathrm{b}}$ from two to seven of the Landsat-8 OLI used in the study. The weights for each band were found according to Equation 8 (SILVA et al., 2016).

$$
p_{b}=\frac{k_{b}}{\Sigma k_{b}}
$$

The planetary albedo $\left(\alpha_{\text {toa }}\right)$, consists of a linear combination of the spectral reflectance in each reflective band $\left(r_{b}\right)$ from 2 to 7 for Landsat-8 OLI their respective weights $p_{b}$, shown in Equation 9.

$$
\alpha_{\text {toa }}=p_{2} \times r_{2}+p_{3} \times r_{3}+p_{4} \times r_{4}+p_{5} \times r_{5}+p_{6} \times r_{6}+p_{7} \times r_{7}
$$

To get a determination of the surface albedo $(\alpha)$, it was necessary to calculate a series of variables such as saturation pressure of the water vapor (s) using Equation 10 (GARRISON \& ADLER, 1990).

$$
e_{s}=0.6108 \cdot \exp ^{\frac{17.27 \times T}{237.3+T}}
$$

Where $\mathrm{e}_{s}$ is the saturation pressure of water vapor $(\mathrm{kPa})$ and $\mathrm{T}$ is the air temperature $\left({ }^{\circ} \mathrm{C}\right)$. It estimated the actual pressure atmospheric water vapor $\left(e_{a}\right)$ (Equation 11) using the $e_{s}$ and the relative humidity of the instantaneous air (RH) (observed in an automatic meteorological station) calculated and is one of the variables used to calculate the precipitable water (W)

$$
e_{a}=\frac{R H \cdot e_{s}}{100}
$$

Precipitable water ( $\mathrm{W}$, given in $\mathrm{mm}$ ) is one of the variables used to determine the atmospheric transmissivity $\left(\tau_{\mathrm{sw}}\right)$, which was found according to Equation 12.

$$
W=0.14 \cdot e_{a} \cdot P_{o}+2.1
$$

Where $\mathrm{P}_{\mathrm{o}}$ is the instantaneous atmospheric pressure in $\mathrm{kPa}$ (extracted from the automatic weather station). The lack of atmospheric pressure data for the 1989 image was obtained according to and Allen et al. (2002) according to Equation 13.

$$
P_{0}=101.3\left(\frac{T_{\text {air }}-0.0065 \cdot z}{T_{\text {air }}}\right)^{5.26}
$$


Where $T_{\text {air }}$ is the air temperature in ${ }^{\circ} \mathrm{C}$ and $\mathrm{z}$ is the altitude of the place. With all these variables determined in this step, the last variable, before reaching the surface albedo, calculated the atmospheric transmissivity $\left(\tau_{s w}\right)$ for days of clear sky, presented in Equation 14.

$$
\tau_{s w}=0.35+0.627 \exp \left[\frac{-0.00146 \cdot P_{o}}{K_{t} \cdot \cos \theta}-0.075\left(\frac{W}{\cos \theta}\right)^{0.4}\right]
$$

Where, $\mathrm{K}_{\mathrm{t}}$ is the turbidity coefficient $\left(\mathrm{K}_{\mathrm{t}}=1.0\right.$ for clean air and $\mathrm{K}_{\mathrm{t}}=0.5$ for extremely turbid or polluted air (ALLEN et al., 2002; 2007). In this work we used it = 1.0 as most current research (SILVA et al., 2016). In this way, after the same pattern of literature as Bastiaanssen et al. (1998b) and Allen et al. (2002), the albedo of the surface $(\alpha)$ Equation 15.

$$
\alpha=\frac{\alpha_{\text {toa }}-\alpha_{\text {atm }}}{\tau_{\mathrm{sw}}^{2}}
$$

Where, $\alpha_{\mathrm{atm}}$ is a reflectance of the atmosphere, which varies between 0.025 and $0.04,0.03$ that value used as recommended in studies by Bastiaanssen (2000) and Silva et al. (2005b).

The NDVI was found through the ratio of the difference in the reflections of the near-infrared $\left(r_{b}\right.$ iv $)$ and the red $\left(r_{b} v\right)$, by the sum, according to Equation 16 (ALLEN et al., 2002).

$$
N D V I=\frac{r_{b I V}-r_{b V}}{r_{b I V}+r_{b V}}
$$

Where the reflections of the near-infrared ( $r_{b}$ iv $)$ and the red $\left(r_{b v}\right)$ correspond to the respective bands 4 and 3 of Landsat- 5 TM and 5 and 4 of Landsat- 8 OLI.

To determine the LAI, which is a biomass indicator of each pixel of the image, it was necessary to get the SAVI vegetation index, given by Equation 17 (ALLEN et al., 2002).

$$
S A V I=\frac{(1+L) \cdot\left(r_{b I V}-r_{b V V}\right)}{\left(L+r_{b I V}+r_{b V}\right)}
$$

Where, $L$ is a variable value of 0.25 (used for dense vegetation), 0.5 (used for intermediate vegetation) and 1.0 (used for low vegetation). The value used was 0.1 , making an analogy to the studies proposed by Allen et al. (2007). 


$$
\mathrm{LAI}=-\frac{\ln \left(\frac{0.69-\mathrm{SAVI}}{0.59}\right)}{0.91}
$$

Where, LAl determined using Equation 18, as suggested by Allen et al. (2002), defined by the ratio between the leaf area of all vegetation per unit area of land used by this vegetation given in $\mathrm{m}^{2} \mathrm{~m}^{-2}$.

An emissivity in each pixel $\left(\varepsilon_{\mathrm{NB}}\right)$ and an $\left(\varepsilon_{0}\right)$ obtained and validated, for $\mathrm{NDVI}>0$ and $\mathrm{LAl}<3$, according to Equations 19 and 20, according to Allen et al. (2002).

$$
\begin{aligned}
& \varepsilon_{\mathrm{NB}}=0.97+0.0033 . \mathrm{LAl} \\
& \varepsilon_{0}=0.95+0.01 . \mathrm{LAl}
\end{aligned}
$$

Where, the conditions followed for pixels with LAl values $\geq 3$, considering $\varepsilon_{N B}=\varepsilon 0=0.98$. For NDVI $<0$, $\varepsilon_{\mathrm{NB}}=0.99$ and $\varepsilon_{0}=0.985$ (ALLEN et al., 2002).

To obtain the surface temperature the spectral radiance of the Landsat- $5 \mathrm{TM} \mathrm{L}_{\mathrm{b} 10}$ thermal bands $\mathrm{L}_{\mathrm{b} 6}$ of Landsat-8 TIRS and the emissivity $\varepsilon_{\mathrm{NB}}$ obtained in the previous step. Given Equation 21, the surface temperature in degrees Kelvin was determined (ALLEN et al., 2002). For a discussion, the results of the temperature converted to degrees Celsius $\left({ }^{\circ} \mathrm{C}\right)$.

$$
\mathrm{T}_{\mathrm{s}}=\frac{\mathrm{K}_{2}}{\left(\frac{\varepsilon_{\mathrm{NB}} \cdot \mathrm{K}_{1}}{\mathrm{~L}_{\mathrm{b}}}+1\right)}
$$

Where, $\mathrm{K}_{1}$ and $\mathrm{K}_{2}\left(\mathrm{~W} \mathrm{~m} \mathrm{~m}^{-2} \mathrm{sr}^{-1}-\mu \mathrm{m}\right)$ are calibration constants of the bands of the Landsat-5 TM thermal (thermal band 6, $\mathrm{L}_{\mathrm{b} 6}, \mathrm{~K} 1=607.76$ and $\mathrm{K} 2=1260.56 \mathrm{~W} \mathrm{~m}^{-2} \mathrm{sr}^{-1} \mu_{\mathrm{m}}^{-1}$ ) and Landsat-8 TIRS (thermal band 10, $\mathrm{L}_{\mathrm{b} 10}$, $\mathrm{K} 1=774.89$ and $\left.\mathrm{K} 2=1321.08 \mathrm{~W} \mathrm{~m}^{-2} \mathrm{sr}^{-1} \mu \mathrm{m}^{-1}\right)$. The calibration coefficients provided by USGS/NASA.

\section{STATISTICAL ANALYSIS}

The results were according to descriptive statistics (minimum, maximum, average, median, mode, standard deviation - SD, and coefficient of variation - CV). The CV (\%) was also assessed as your variability, according to the criteria of classification of Warrick \& Nielsen (1980), where CV < 12\% (low variability), CV between 12 and 60\% (average variability) and CV > 60\% (high variability). 


\section{RESULTS AND DISCUSSION}

Figure 3 presents the thematic maps of spatial-temporal analysis of the surface albedo $(\alpha)$ of the hydrographic basin of the Exu stream, where Figures $3 \mathrm{~A}, 3 \mathrm{~B}$, and $3 \mathrm{C}$ represent albedo for a dry period in years classified as dry, normal, and rainfall, respectively. The colors in blue tones refer to the lowest albedo values in the maps and occur mostly in dense vegetation (dark blue), intermediate values being represented by light green to yellow colors and larger values being represented by orange and red colors. You can see extremely high values (red pixels) appearing south of Figure 3.

Figure 3. Spatial-temporal distribution of the surface albedo in the hydrographic basin of the Exu stream on 09/20/2016 (A) of the dry year, 01/09/2009 (B) normal and 09/26/1989 (C) rainfall.

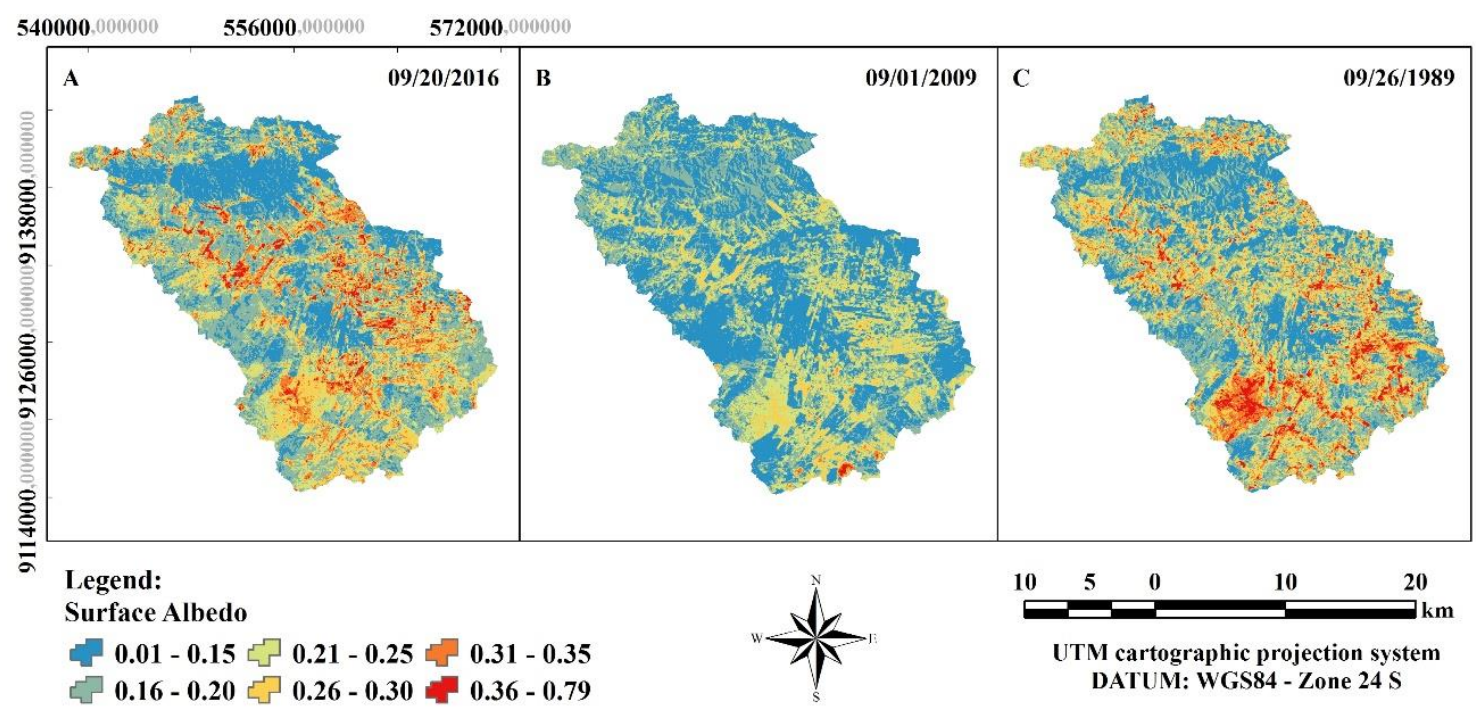

The maps present visually similar characteristics of possibly degraded or in process of degradation, located mainly to the southwest of the basin, as well as preserved areas in the upper part of the central north. The surface albedo ranged from 0.01 to 0.79 . Values higher than 0.31 represented in orange color observed on a slightly vegetated surface such as values higher than 0.36 represented by the red color detected in exposed soils and cloud top (0.79), which did not influence the analysis.

The results are consistent with research conducted by Dantas et al. (2010), they found values greater than 0.34 , indicating the little vegetated soil and top of clouds by using images from sensors Landsat-5 TM AVHRR (Advanced and Very High-Resolution Radiometer), NOAA to estimate the surface albedo in an area east of Ceará, near the municipality of Quixeré on areas occupied by irrigated agriculture and areas of native vegetation, the authors also detected that the highest values of albedo occurred in the months of August and October 2005 and related them as cause to drought in this period, highlighted as the main reason for the high 
values of albedo detected in the present work, since September is historically the driest month for the region studied.

Table 4 highlights the statistical analysis of albedo, which according to Warrick \& Nielsen (1980) classification has a medium variability behavior, with CV varying between 20 and $50 \%$.

Table 4. Statistical parameters of the surface albedo for the hydrographic basin of the Exu stream.

\begin{tabular}{llllll}
\hline \multirow{2}{*}{ Date } & \multicolumn{5}{l}{ Surface albedo $(\boldsymbol{\alpha})$} \\
\cline { 2 - 6 } & Minimum & Maximum & Medium & SD & CV (\%) \\
\hline $09 / 26 / 1989$ & 0.02 & 0.30 & 0.08 & 0.03 & 40 \\
$09 / 01 / 2009$ & 0.04 & 0.79 & 0.15 & 0.03 & 20 \\
$09 / 20 / 2016$ & 0.01 & 0.47 & 0.10 & 0.05 & 50 \\
\hline
\end{tabular}

Alves et al. (2017) also using Landsat image 8 OLI dated September 20-2016 in three representative points inserted in the Pajeú River Basin, where point " $A$ " equivalent to the Serra do Arapuá presented a value of 0.15 , point " $\mathrm{B}$ " equivalent to the Açude Serrinha presented a value of 0,7 and point " $\mathrm{C}$ " representing the urban area of Serra Talhada presented a value of 0,3 albedo of the surface, corroborating with the values for similar points in the basin understudy on the same date. Using Landsat-8 OLI to semiarid region, Silva et al. (2016) found in agricultural areas with albedo values between 0.15 and 0.2 and water bodies between 0.03 and 0.08 , however in this study it is possible to see in some stretches of the course of the stream values greater than 0.15 , which refers to the possibility of ground taken by little dense or partly exposed, the stream may be dry and/or silted.

The NDVI vegetation index for the hydrographic basin of the Exu stream is presented in the thematic map of Figure 4 for the days 09/20/2016 (A), 09/01/2009 (B), and 09/26/1989 (C). It is possible observed that reddish and orange tones for lower values of NDVI related to soil areas with little or no vegetation, yellow and green colors indicated intermediate values related to areas of Caatinga with less vigorous vegetation, and the blue and dark blue tones are the areas with more dense vegetation. The minimum and maximum NDVI values ranged from -0.63 to 0.86 . Albuquerque et al. (2014) found that the NDVI presented values ranging from 0.01 to 0.29 in areas of exposed soil and sparse vegetation, while the intervals between 0.3 and 0.5 represent less dense vegetation and those greater than 0.5 indicated that the vegetation presented a good phenological state, being the dense vegetation represented by the NDVI superior to 0.7 , corroborating with this work. 
Figure 4. Spatial-temporal distribution of the NDVI vegetation index in the hydrographic basin of the Exu stream on 09/20/2016 (A) of the dry year, 09/01/2009 (B) normal and 09/26/1989 (C) rainfall.

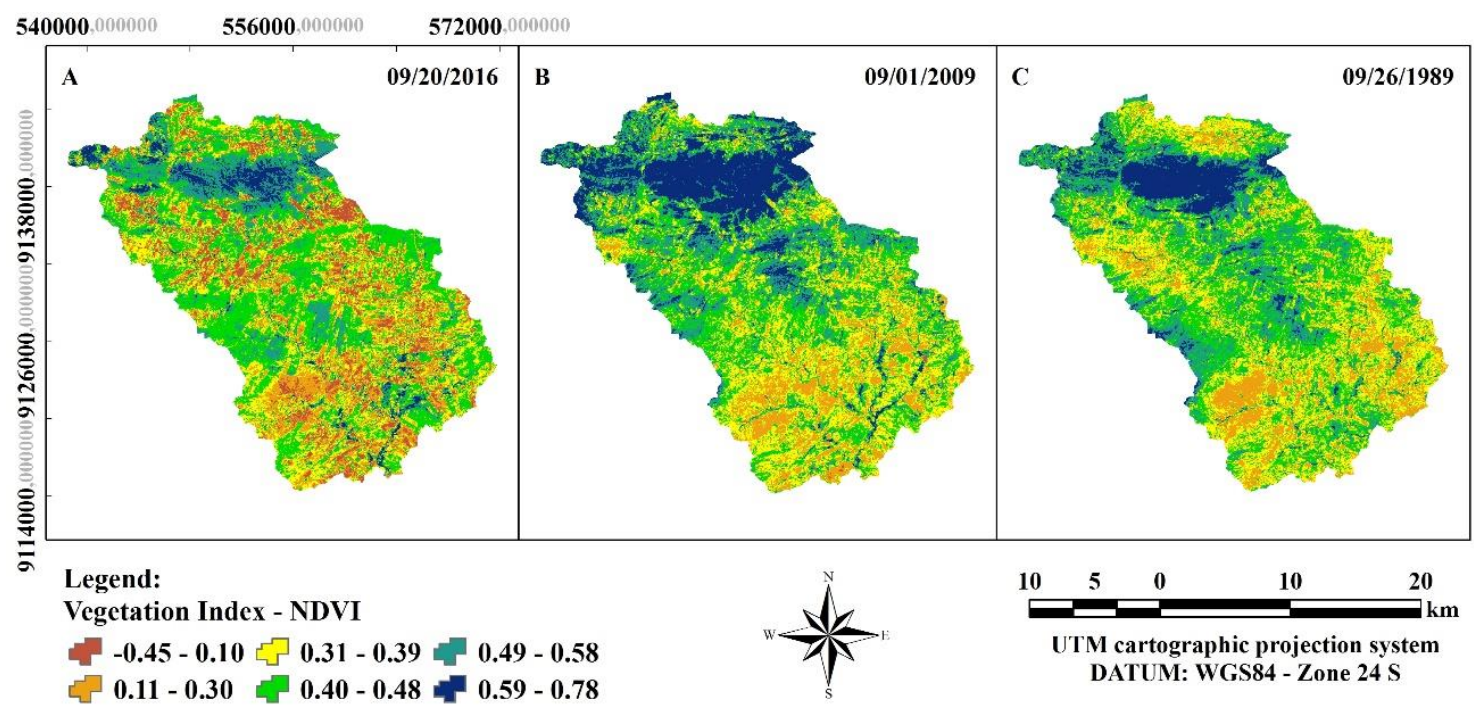

The NDVI index showed sensitivity to dense vegetation cover since it preserves a pattern of behavior of the green condition of the vegetation. This condition favors, mainly, the monitoring of the Caatinga's spatial dynamics for different seasonality.

Table 5 shows the statistical analysis of the NDVI, which according to Warrick \& Nielsen (1980) classification criteria, as well as albedo, showed a medium variability behavior (CV ranged from 22 to $27 \%$ ). Among the images analyzed, Figure 4A was the one that showed a lower average value, which is explained by the fact of having less rain antecedent. It is worth mentioning that as well as the dry season for the region, the study area in the Brazilian semiarid, where the Caatinga vegetation has a physiological defense condition such as leaf fall (RODRIGUES et al., 2020; SILVA et al., 2019b; BEZERRA et al., 2014).

Table 5. Statistical parameters of NDVI vegetation index for the hydrographic basin of the Exu stream.

\begin{tabular}{llllll}
\hline \multirow{2}{*}{ Date } & \multicolumn{2}{l}{ Vegetation Index - NDVI } & & \\
\cline { 2 - 6 } & Minimum & Maximum & Medium & SD & CV (\%) \\
\hline $09 / 26 / 1989$ & -0.45 & 0.84 & 0.46 & 0.11 & 24 \\
$09 / 01 / 2009$ & -0.45 & 0.78 & 0.44 & 0.12 & 27 \\
$09 / 20 / 2016$ & -0.63 & 0.86 & 0.37 & 0.08 & 22 \\
\hline
\end{tabular}

Santos \& Galvíncio (2013) observed densely vegetated areas, with a predominance of arboreal Caatinga, ranging from 0.71 to 0.80 , and in areas with sparse vegetation, predominantly shrub Caatinga, NDVI values between 0.51 and 0.70 similar to this study.

The Soil Vegetation Index (SAVI) is shown in Figure 5. The thematic maps of Figures 5A, 5B, and $5 C$ represent the dry period for years classified as Dry, Normal, and Rainfall, respectively. It is possible to observed for these images a 
predominance shades in warmer colors like red, orange, and yellow for values ranging from -0.3 to 0.33 , denoting regions with little or no vegetation.

The SAVI index is essential in the study of dry areas, that is, in semi-arid regions. Therefore, it presents a special domain of characterization of vegetation corrected to the effects of the soil, being effective in the monitoring of regions with water deficit conditions.

Figure 5. Spatial-temporal distribution of the SAVI vegetation index in the hydrographic basin of the Exu stream on 09/20/2016 (A) of the dry year, 09/01/2009 (B) normal and 09/26/1989 (C) rainfall.

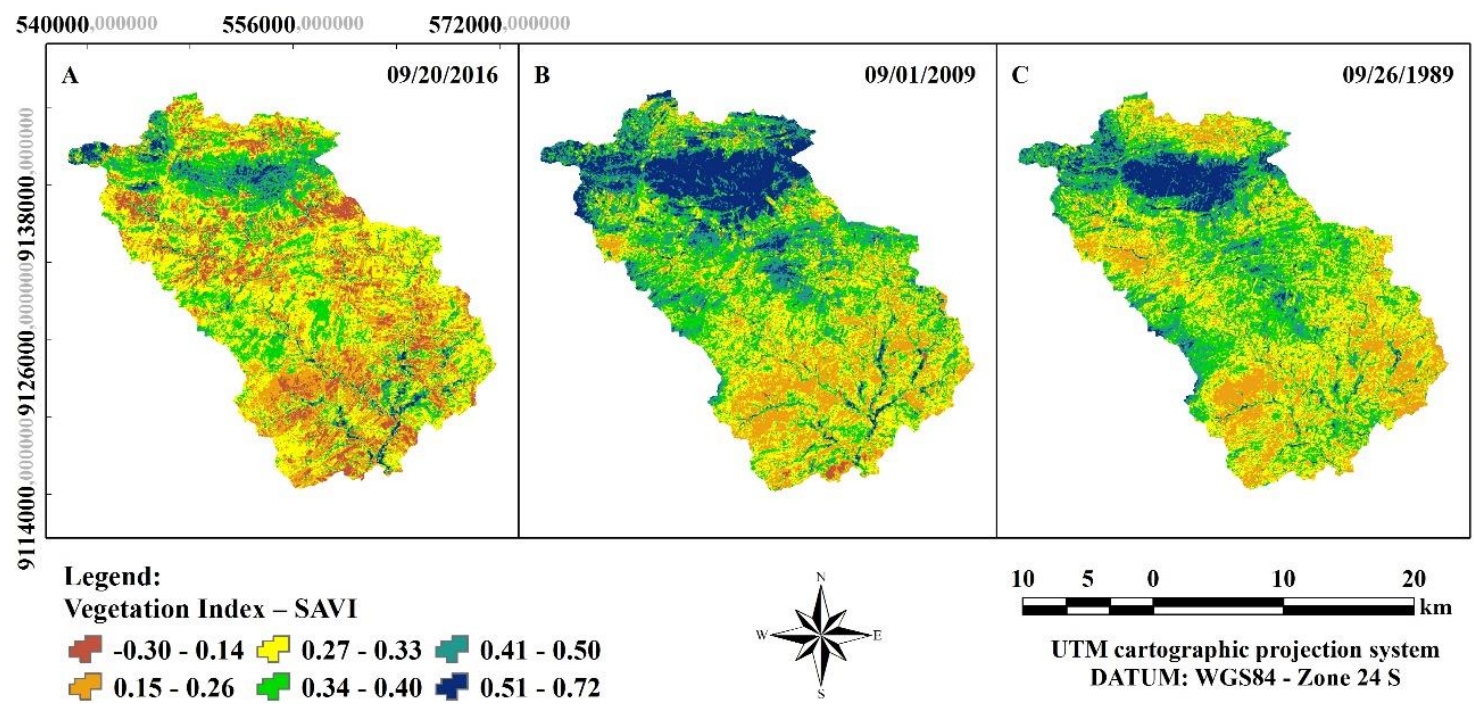

The results obtained for the SAVI are similar to those of the NDVI, both visually and in values, so the SAVI is an index adapted from the NDVI where the insertion of the constant L, used to soften the background effects of the soil. Ribeiro et al. (2016) also cite this similarity between NDVI and SAVI. The values found for SAVI were lower than those obtained for NDVI, differently from the results obtained by Rêgo et al. (2012) who, when studying these vegetation indices for the municipality of São Domingos do Cariri-PB, find lower values for NDVI with the SAVI, referring to a different behavior when estimating vegetation indices in a river basin and a municipality.

The averages found varied from 0.30 to 0.36 , which is the year 2009 that presented the highest average, which attributed to the fact the previous precipitation was higher than in the other images. In rainfall periods, Ribeiro et al. (2016) when estimated vegetation indices in the Pajeú river basin, found a predominance of Caatinga-covered soils with SAVI indexes higher than 0.41 in 2005 and 2014, which are similar to the values of Caatinga found in this work. The Caatinga biome has high resilience power, where the rapid formation of biomass occurs, that is, the increase in leaf canopy in response to rainfall regimes (SILVA et al., 2019b; LINS et al., 2017; RODRIGUES et al., 2009; ARRAES et al., 2012).

The statistical parameters found for SAVI in the study area shown in Table 6. As in NDVI, SAVI showed a behavior of mean variability according to Warrick \& Nielsen (1980) classification criteria. 
Table 6. Statistical parameters of the vegetation index SAVI to the hydrographic basin of the Exu stream.

\begin{tabular}{llllll}
\hline \multirow{2}{*}{ Date } & \multicolumn{2}{l}{ Vegetation Index - SAVI } & & \\
\cline { 2 - 6 } & Minimum & Maximum & Medium & SD & CV (\%) \\
\hline $09 / 26 / 1989$ & -0.28 & 0.75 & 0.35 & 0.09 & 26 \\
$09 / 01 / 2009$ & -0.30 & 0.72 & 0.36 & 0.11 & 30 \\
$09 / 20 / 2016$ & -0.20 & 0.77 & 0.30 & 0.06 & 20 \\
\hline
\end{tabular}

The lowest values of SAVI, as well as NDVI, observed in cloud tops (negative values), soil exposed or with little vegetation, the highest values were on mountain areas, the highest part of the basin, where the Caatinga is found more preserved, being located to the north-central of Figures $5 \mathrm{~A}, 5 \mathrm{~B}$ and $5 \mathrm{C}$ and the south in the lines of drainage of the basin.

The leaf area index (LAI) of the hydrographic basin of the Exu stream is shown in Figure 6 . The LAI, as well as NDVI and SAVI, features higher values in images with greater antecedent precipitation (Figure 6B and 6C), which highlights the precipitation factor as decisive in increasing vegetation indices. The areas with the highest density of vegetation, that is, with high photosynthetic activity, highlighted in NDVI, SAVI, and also in IAF are directly related to the maintenance of soil moisture in the basin. Silva (2019a) when analyzing the vegetation indexes of the hydrographic basin inserted in the municipality of São João do Cariri-PB, also in the semi-arid region observed that the vegetation presented a higher density in the areas corresponding to the higher places or on the margins of the water bodies, corroborating with the present study.

Figure 6. Spatial-temporal distribution of the LAI vegetation index in the hydrographic basin of the Exu stream on 09/20/2016 (A) of the dry year, 01/09/2009 (B) normal and 09/26/1989 (C) rainfall.

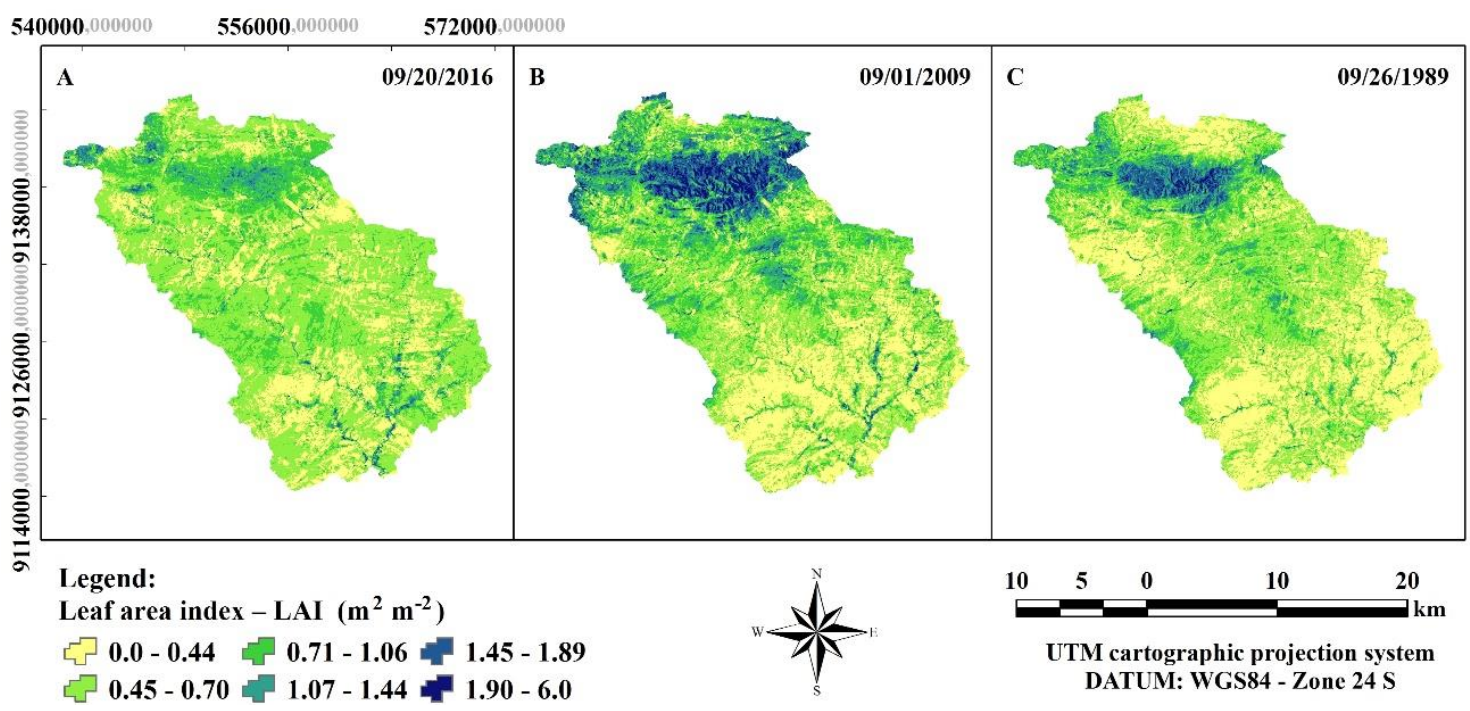

The highest values of LAI represented by values ranging from dark green to dark blue, which are most evident in the mountains area in the upper part of the preserved Caatinga basin, north-central of Figures $6 \mathrm{~A}$, $6 \mathrm{~B}$, and $6 \mathrm{C}$, and to the south in the drainage of the basin, which occurs similarly in NDVI and SAVI. 
Table 7 shows that the minimum and maximum values did not vary for all the images. Among the images, that of 09/01/2009 (Figure 6B) was the highest mean when compared to Figures 6A and 6C, with little difference to the image of 09/26/1989 (Figure 6C). According to Warrick \& Nielsen (1980) classification criteria, Figure $6 \mathrm{~A}$ and $6 \mathrm{C}$ presented mean variability differently from Figure $6 \mathrm{~B}$, which presented a high variability differentiating it from the other vegetation indices NDVI and SAVI.

Table 7. Statistical parameters of the LAl vegetation index for the hydrographic basin of the Exu stream.

\begin{tabular}{llllll}
\hline \multirow{2}{*}{ Date } & \multicolumn{2}{l}{ Vegetation Index - LAI $\left(\mathbf{m}^{\mathbf{2}} \mathbf{~ m}^{-2}\right)$} & & \\
\cline { 2 - 6 } & Minimum & Maximum & Medium & SD & CV (\%) \\
\hline $09 / 26 / 1989$ & 0.0 & 6.0 & 0.67 & 0.40 & 60 \\
$09 / 01 / 2009$ & 0.0 & 6.0 & 0.71 & 0.45 & 63 \\
$09 / 20 / 2016$ & 0.0 & 5.98 & 0.46 & 0.19 & 41 \\
\hline
\end{tabular}

The vegetation indices highlighted the pattern of spatio-temporal behavior of the vegetation cover, showing the conditions of resilience and water deficit in the hydrographic basin of the Exu stream, controlled by the climatic variability of the semiarid region.

The surface temperature of the hydrographic basin of the Exu stream is represented by the thematic map shown in Figure 7 for the days 09/20/2016 (A), 09/01/2009 (B), and 09/26/1989 (C). The lower values for surface temperature exposed in tones of blue, intermediate values observed in light green and yellow tones, and the highest values were presented in orange and red tones. The lowest temperatures were observed in small water bodies and cloud tops and at higher altitude places with preserved vegetation corroborating Bezerra et al. (2014), which also recorded lower raised surface temperatures with higher altitudes. The highest temperatures were observed in regions with exposed soil or low vegetation, this behavior was also perceived by Oliveira et al. (2014) in a study in the state of Pernambuco.

Figure 7. Spatial-temporal distribution of the surface temperature in the hydrographic basin of the Exu stream on 09/20/2016 (A) of the dry year, 09/01/2009 (B) normal, and 09/26/1989 (C) rainfall.

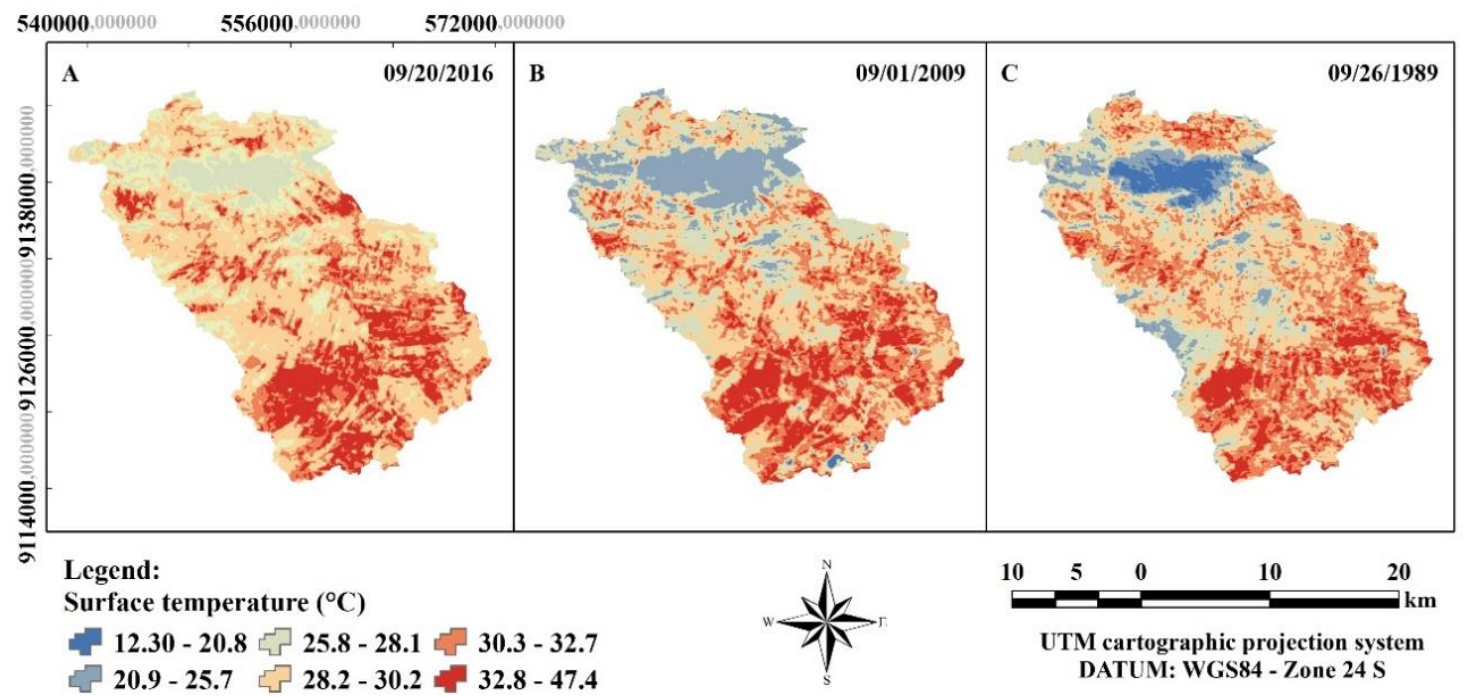


When analyzing the same pixel in a preserved Caatinga area was found for Figures 6A (09/20/2016), 6B (09/01/2009), and $6 C$ (09/26/1989) surface temperature values of $29.35,23.1$, and $22.6^{\circ} \mathrm{C}$ respectively. In the statistical parameters shows in Table 8, it observed that the values ranged from the minimum value that refers to cloud-top $12.31{ }^{\circ} \mathrm{C}$ for Figure $6 \mathrm{~B}(09 / 01 / 2009)$, at $47.45{ }^{\circ} \mathrm{C}$ for the maximum value found in Figure $6 \mathrm{~A}$ $(09 / 20 / 2016)$ that has a relation with exposed soil. All the images presented a low variability according to the classification criteria of Warrick \& Nielsen (1980).

Table 8. Statistical parameters of the surface temperature for the hydrographic basin of the Exu stream.

\begin{tabular}{llllll}
\hline \multirow{2}{*}{ Date } & \multicolumn{2}{l}{ Surface temperature $\left({ }^{\circ} \mathrm{C}\right)$} & & \\
\cline { 2 - 6 } & Minimum & Maximum & Medium & SD & CV (\%) \\
\hline $09 / 26 / 1989$ & 21.35 & 35.99 & 29.16 & 2.18 & 7 \\
$09 / 01 / 2009$ & 12.31 & 38.43 & 29.39 & 2.97 & 10 \\
$09 / 20 / 2016$ & 28.74 & 47.45 & 39.15 & 3.37 & 9 \\
\hline
\end{tabular}

Similar to the present study, Lins et al. (2017) when studied the Arcoverde municipality semiarid area of the state of Pernambuco, detected a temperature increase of $15.5{ }^{\circ} \mathrm{C}$ when moved from regions with abundant vegetation to those of exposed soil.

In general, it was observed that the increase in vegetation indices reflected in lower values for albedo and surface temperature. For a better understanding of the observed values, mainly albedo, soil moisturerelated studies with such parameters for this basin are suggested for future work.

\section{CONCLUSIONS}

Remote sensing as a tool to investigate the use and occupation of the soil was of great importance in the environmental monitoring of the hydrographic basin of the Exu stream, during the 27 years, and may aid in the management and conservation of soil.

The analysis of the biophysical parameters of the surface albedo, NDVI, SAVI, LAI, and surface temperature allowed an efficient evaluation of spatial-temporal dynamics in the surface of the basin.

It was possible to observed that the vegetation dynamics did not differ between orbital images, regardless of whether the year was dry, normal, or rainfall, because the vegetation growth response occurs on a daily scale, depending on precipitation. 


\section{ACKNOWLEDGEMENTS}

The authors thank the Graduate Program in Agricultural Engineering and the Universidade Federal Rural de Pernambuco to support the research, as well as CAPES and CNPq for provided the scholarship. Also to INMET for providing surface meteorological data.

\section{REFERENCES}

ALBUQUERQUE, E.M., ANDRADE, S.C.P., MORAIS, H.F., DINIZ, J.M.T., SANTOS, C.A.C., 2014. Análise do comportamento do NDVI e NDWI sob diferentes intensidades pluviométricas no município de Souza-PB. Revista Estudos Geoambientais, 1: 1-11.

ALLEN, R.G., TASUMI, M., TREZZA, R., 2007. Satellite-Based energy balance for mapping evapotranspiration with internalized calibration (METRIC) - Model. Journal of Irrigation and Drainage Engineering, 133: 380-394.

ALLEN, R.G., TREZZA, R., TASUMI, M., 2002. Surface energy balance algorithms for land. Advance training and Users Manual, Idaho Implementation, 1.0: 98.

ALVARES, C.A., STAPE, J.L., SENTELHAS, P.C., MORAES, G., LEONARDO, J., SPAROVEK, G., 2013. Köppen's climate classification map for Brazil. Meteorologische Zeitschrift, 22, 711-728.

ALVES, L.E.R., GOMES, H.B., SANTOS, M.N., FREITA, I.G.F., 2017. Balanço de radiação através do Landsat-8 na bacia do Rio Pajeú. Revista do Departamento de Geografia, 33: 117-127.

ARRAES, F.D.D., ANDRADE, E.M., SILVA, B.B., 2012. Dinâmica do balanço de energia sobre o açude Orós e suas adjacências. Revista Caatinga, 25: 119-127.

BASTIAANSSEN, W., THORESON, B., CLARK, B., DAVIDS, G., 2010. Discussion of "Application of SEBAL Model for Mapping Evapotranspiration and Estimating Surface Energy Fluxes in South-Central Nebraska" by Ramesh K. Singh, Ayse Irmak, Suat Irmak, and Derrel L. Martin. Journal of Irrigation and Drainage Engineering-Asce, 136: 282-283.

BASTIAANSSEN, W.G.M., 2000. SEBAL - Based Sensible and Latent Heat Fluxes in the Irrigated Gediz Basin, Turkey. Journal of Hidrology, 229: 87-100.

BASTIAANSSEN, W.G.M., MENENTI, M., FEDDES, R.A., HOLTSLAG, A.A.M., 1998a. A remote sensing surface energy balance algorithm for land (SEBAL) 1. Formulation. Journal of Hydrology, 212-213: 198-212.

BASTIAANSSEN, W.G.M., PELGRUM, H., WANG, J., MA, Y., MORENO, J.F., ROERINK, G.J., VAN DER WAL, T., 1998b. A remote sensing surface energy balance algorithm for land (SEBAL) 2. Validation. Journal of Hydrology, 212-213: 213-229.

BEZERRA, J.M., MOURA, G.B.A., SILVA, B.B., LOPES, P.M.O., SILVA, E.F.F., 2014. Parâmetros biofísicos obtidos por sensoriamento remoto em região semiárida do estado do Rio Grande do Norte, Brasil. Revista Brasileira de Engenharia Agrícola e Ambiental, 18: $73-$ 84.

BRANDT, M., ROMANKIEWICZ, C., SPIEKERMANN, R., \& SAMIMI, C., 2014. Environmental change in time series-An interdisciplinary study in the Sahel of Mali and Senegal. Journal of Arid Environments, 105: 52-63.

CHANDER, G., MARKHAM, B.L., HELDER, D.L., 2009. Summary of current radiometric calibration coefficients for Landsat MSS, TM, ETM+, and EO-1 ALI sensors. Remote Sensing of Environment, 113: 893-903.

CHAVEZ J. P. S., 1988. An improved dark-object subtraction technique for atmospheric scattering correction of multispectral data. Remote Sensing of Environment, 24:459-479.

CHAVEZ J. P. S., 1989. Radiometric calibration of Landsat thematic mapper multispectral images. Photogrammetric Engineering and Remote Sensing, 55:1285-1294.

CPRM. Companhia de Pesquisa e Recursos Minerais. Serviço Geológico do Brasil. Projeto cadastro de fontes de abastecimento por água subterrânea: Diagnostico do município de Serra Talhada. Recife: CPRM/PRODEEM, 2005. 12 p.

DANTAS, F.R.C., BRAGA, C.C., SOUZA, E.P., SILVA, S.T.A., 2010. Determinação do albedo da superfície a partir de dados AVHRR/NOAA e TM/ Landsat-5. Revista Brasileira de Meteorologia, 25: 24-31. 
ENGLE, N.L., 2012. The role of drought preparedness in building and mobilizing adaptive capacity in states and their community water systems. Climatic Change, 118: 291-306.

GARRISON, J.D., ADLER, G.P., 1990. Estimation of precipitable water over the United State for application to the division of solar radiation into its direct and diffuse components. Solar Energy, 44: 225-241.

GUTIÉRREZ, A.P.A., ENGLE, N.L., DE NYS, E., MOLEJÓN, C., \& MARTINS, E.S., 2014. Drought preparedness in Brazil. Weather and Climate Extremes, 3: 95-106.

HASTENRATH, S., 2012. Exploring the climate problems of Brazil's Nordeste: a review. Climatic Change, 112: 243-251.

IQBAL, M., 1983. An introduction to solar radiation. London: Academic Press., 390 p.

KÖPPEN, W., 1936. Das geographische System der Klimate. Köppen, W, R. Geiger (Eds.): Handbuch der Klimatologie. Gebrüder Bornträger, Berlin, 1: 1-44, part C.

LINS, F.A.C., ARAÚJO, D.C.S., SILVA, J.L.B., LOPES, P.M.O., OLIVEIRA, J.D.A., SILVA, A. T.G.C.S.G, 2017. Estimativa de parâmetros biofísicos e evapotranspiração real no semiárido Pernambucano utilizando sensoriamento remoto. Irriga, 1: 64-75.

MARIANO, D.A., DOS SANTOS, C.A., WARDLOW, B.D., ANDERSON, M.C., SCHILTMEYER, A.V., TADESSE, T., \& SVOBODA, M.D., 2018. Use of remote sensing indicators to assess effects of drought and human-induced land degradation on ecosystem health in Northeastern Brazil. Remote Sensing of Environment, 213: 129-143.

MOURA, M.S.B., GALVÍNCIO, J.D., BRITO, L.T.L., SOUZA, L.S.B., S.Á., I.I.S., SILVA, T.G.F., 2007. Clima e água de chuva no Semi-Árido. In: Brito, LTL, Moura, MSB, Gama, GFB (Ed.). Potencialidades da água de chuva no Semi-Árido brasileiro. Petrolina: Embrapa Semi-Árido. cap. 2: 37-59.

OLIVEIRA, L.M., MONTENEGRO, S.M., SILVA, B.B., ANTONINO, A.C., MOURA, A.E., 2014. Evapotranspiração real em bacia hidrográfica do Nordeste brasileiro por meio do SEBAL e produtos MODIS. Revista Brasileira de Engenharia Agrícola e Ambiental, 18: 1039-1046.

PACHECO, A.P., LUCAS, A.A., SILVA, B.B., MARIANO, G., 2014. Desertificação: Contextualização e Sensoriamento Remoto. Estudos Geológicos, 24: 109-126.

PALÁCIO, H.A.Q., ANDRADE, E.M., SANTOS, J.C.N., ARAÚJO NETO, J.R., BRASIL, P.P., 2013. Energy evaluation of semi-arid watersheds under different management strategies. Transactions of the ASABE, 56: 1-7.

RÊGO, S.C.A., LIMA, P.P.S., LIMA, M.N.S., MONTEIRO, T.R.R., 2012. Análise comparativa dos índices de vegetação NDVI e SAVI no município de São Domingos do Cariri-PB. Revista Geonorte, 2: 1217-1229.

RIBEIRO, E.P., NÓBREGA, R.S., FILHO, F.O.M., MOREIRA, E.B.M., 2016. Estimativa dos índices de vegetação na detecção de mudanças ambientais na bacia hidrográfica do rio Pajeú. Geosul, 31: 59-92.

RODRIGUES, J.A.M., LOPES, P.M.O., SILVA, J.L.B., ARAÚJO, H.L., SILVA, M.V., SANTOS, A., ALBUQUERQUE M.G.B., 2020. Spatialtemporal dynamics of Caatinga vegetation cover by remote sensing in the Brazilian semiarid region. DYNA, 87:109-117.

RODRIGUES, J.D., ANDRADE, E.D., TEIXEIRA, A.D.S., SILVA, B.D., 2009. Sazonalidade de variáveis biofísicas em regiões semiáridas pelo emprego do sensoriamento remoto. Engenharia Agrícola, 29: 452-465.

RODRIGUEZ, R.D.G., SINGH, V.P., PRUSKI, F.F., CALEGARIO, A.T., 2015. Using entropy theory to improve the definition of homogeneous regions in the semi-arid region of Brazil. Hydrological Sciences Journal, 7: 2096-2109.

SANTOS, A.M., GALVÍNCIO, J.D., 2013. Mudanças climáticas e cenários de susceptibilidade ambiental à desertificação em municípios do estado de Pernambuco. Revista Eletrônica de Geografia, 5: 66-83.

SILVA, B.B., BRAGA, A.C., BRAGA, C.C., OLIVEIRA, L.M., MONTENEGRO, S.M., BARBOSA JUNIOR, B., 2016. Procedures for calculation of the albedo with OLI-Landsat 8 images: Application to the Brazilian semi-arid. Revista Brasileira de Engenharia Agrícola e Ambiental, 20: 3-8.

SILVA, B.B., LOPES, G.M., AZEVEDO, P.V., 2005a. Balanço de radiação em áreas irrigadas utilizando imagens Landsat 5 - TM. Revista Brasileira de Meteorologia, 20: 243-252.

SILVA, B.B., Lopes, G.M., Azevedo, P.V., 2005b. Determinação do albedo de áreas irrigadas com base em imagens Landsat 5 TM. Revista Brasileira de Agrometeorologia, 13: 201-211. 
SILVA, J.L.B.; MOURA, G.B.A.; LOPES, P.M.O.; SILVA, E.F.F.; ORTIZ, P. F. S.; SILVA, D.A.O.; SILVA, M.V.; GUEDES, R.V.S., 2020. SpatialTemporal Monitoring of the Risk of Environmental Degradation and Desertification by Remote Sensing in a Brazilian Semiarid Region. Revista Brasileira de Geografia Física, 13:544-563.

SILVA, G.J.F.; MACÊDO, M.L.A.; SILVA, R.M., 2019a. Caracterização espaço-temporal das tipologias vegetais em ambiente de caatinga degradada: quantificação por meio de variáveis biofísicas. Ateliê Geográfico, 13:92-110.

SILVA, J.L.B.; MOURA, G.B.A.; SILVA, E.F.F; LOPES, P.M.O.; SILVA, T.T.F.; LINS, F.A.C.; SILVA, D.A.O.; ORTIZ, P.F.S., 2019. Spatialtemporal dynamics of the Caatinga vegetation cover by remote sensing in municipality of the Brazilian semi-arid. Revista Brasileira de Ciências Agrárias, 14:1-10.

WARRICK, A.W., NIELSEN, D.R., 1980. Spatial variability of soil physical properties in the field. In: Hillel, D. (ed.). Applications of soil physics. New York: Academic Press, 319-344.

XAVIER, T.M.B.S., SILVA, J.F., REBELLO, E.R.G., 2002. A Técnica dos Quantis e suas Aplicações em Meteorologia, Climatologia e Hidrologia em Regiões Brasileiras. Brasília-DF: Thesaurus Editora de Brasília Ltda. 144 p.

ZHANG, K., KIMBALL, J.S., RUNNING, S.W., 2016. A review of remote sensing based actual evapotranspiration estimation. Wiley Interdisciplinary Reviews: Water, 3: 834-853. 